This PDF is a selection from an out-of-print volume from the National Bureau of Economic Research

Volume Title: Money in Historical Perspective

Volume Author/Editor: Anna J. Schwartz

Volume Publisher: University of Chicago Press

Volume ISBN: 0-226-74228-8

Volume URL: http://www.nber.org/books/schw87-1

Publication Date: 1987

Chapter Title: Clark Warburton: Pioneer Monetarist

Chapter Author: Michael D. Bordo, Anna J. Schwartz

Chapter URL: http://www.nber.org/chapters/c7504

Chapter pages in book: (p. 234 - 254) 


\title{
Clark Warburton: Pioneer Monetarist
}

\author{
Michael D. Bordo and Anna J. Schwartz
}

\subsection{Introduction}

The central question debated in monetary economics for at least the past decade has been whether changes in the quantity of money are the dominant independent determinant of cyclical changes in economic activity. The challenge to the Keynesian view of business fluctuations represented by the question has been taken up by a significant number of economists. Thirty years ago by contrast a lone voice expressed reservations about Keynesian neglect of the role of monetary change in analyzing business fluctuations. The voice was that of Clark Warburton who persisted in arguing the merits of his case, undaunted by the isolation of his position. By this date, he is a patriarchal figure. A retrospective on Warburton's contribution to monetary thought is long overdue.

A salient characteristic of Warburton's work is that it was empirically oriented. His autobiographical discussion of the development of his ideas traces the shifts in emphasis they underwent as his examination of statistical data and the literature on banks and business cycles altered his perception. Antedating this examination, at the start of his career, he echoed conventional views on changes in bank reserves and the volume of bank credit as passive factors in cyclical episodes. He did not entertain these views for long, however. By the early 1940s, after studying annual tabulations for 1920-35 of bank deposits, by counties, he became convinced that the role of money "was an active factor in producing the downswing of 1930-33" and that the contraction of the stock of money that was then experienced had been avoidable. Sub-

The authors are grateful to Clark Warburton for his careful review of this paper. 
sequent analysis of quarterly data that he developed for the interwar period "led to emphasis, in articles published after 1945, on an erratic money supply as the chief originating factor in business recessions and not merely an intensifying force in the case of severe depressions" (1966, Introduction, p. 9). This in turn led him to focus on the theory of the founders of the Federal Reserve System, its operating procedures, and measures to improve monetary control. In addition, he extended back to Revolutionary times observations on the quantity of money and the timing of business cycles.

The structure of ideas that emerged from the empirical work was essentially completed in the years 1945-53. Warburton, who found time for his investigations when he could be spared from more immediate problems of the Federal Deposit Insurance Corporation, where he was employed as an economist from 1934 until his retirement in 1965 , suspended his independent studies in 1953. In part this action may have been dictated by the withdrawal of permission for him to engage in his research on FDIC time. In part one conjectures that Warburton may well have been disheartened by the failure of his ideas to gain adherents during the years of the ascendancy of Keynesianism. At any rate, Warburton did not resume his studies until 1962 when he was employed for three months by the House Banking and Currency Committee. Thereafter he published widely on the range of issues his earlier studies encompassed, based on a revision and extension of the interwar data to cover the period 1919-65. The resumption of Warburton's monetary studies coincided with the upsurge of interest in monetary theory and empirical research that has attracted a new generation of economists. Belatedly, he won recognition as a forerunner of ideas that became current long after he had first enunciated them.

In reviewing Warburton's contribution, it is convenient to begin with his own classification of his papers: the role of money in business fluctuations (section 9.2); the relation of the quantity and velocity of money to effective demand and the price level (section 9.3); the relation of saving, debt, and liquidity preference to monetary policy and business instability (section 9.4); central banking and monetary policy (section 9.5); improvement of monetary policy (section 9.6); and ending with an evaluation of his life work (section 9.7).

\subsection{Money and Business Cycles}

In his earliest writings, Warburton subscribed to a real theory of the cycle. ${ }^{1}$ Subsequently, he linked changes in real forces to changes in debt, which led to changes in bank assets and deposits, and hence changes in the quantity of money, with changes in velocity acting as an accommodating factor. In formulating a business cycle hypothesis 
in $1942,{ }^{2}$ Warburton described money as an accentuating factor capable of converting a mild contraction into a deep recession. By 1945, he was convinced that this emphasis was in error. Study of the data impelled him to emphasize instead "an erratic money supply as the chief originating factor in business recessions and not merely an intensifying force in the case of severe depressions"' (1966, Introduction, p. 9).

Once he arrived at this view, Warburton proceeded to criticize contemporary economists for failing to pay heed to the traditional theory of monetary disequilibrium. ${ }^{3}$ Economists in the late nineteenth and twentieth centuries understood the importance of monetary disturbances, especially those occurring in the banking sector, as the key cause of business fluctuation. ${ }^{4}$ Yet in the second quarter of the twentieth century, the role of variations in the quantity of money and its velocity of circulation, bank reserves, and monetary policy was neglected. ${ }^{5}$ Warburton set himself the task of redressing that neglect.

Using deviations from trend of quarterly data, 1918-47, he found that negative deviations from trends in bank reserves and the quantity of money preceded turning points in the value of sales of final products, which led, first, quantities sold, then prices, and finally the circuit velocity of money. ${ }^{6}$ Approximately twenty years later, Warburton updated his series to 1965 . Using two measures of effective demand and two measures of money, all in detrended form, he found, as in his earlier work, that deviations from trend of money generally preceded turning points in business, while those of velocity generally followed. ${ }^{7}$

A feature of Warburton's work is his explanation for the timing of the breakdown of changes in aggregate spending into changes in prices and output. The initial impact of a decline (rise) in spending will be on output, he noted, ${ }^{8}$ because

we may assume that in general, market prices are stated by sellers. The decline in spending therefore may be expected to have its initial impact primarily upon the quantity of goods purchased at prevailing prices; with the reduction in prices at which goods are offered and sold occurring chiefly as a result of accumulating inventories and retardation in the receipt of new orders. [1966, ch. 8 (1948b), p. 188]

In updating his work, Warburton found that downturns in 1950-65 exhibited a decline only in output. ${ }^{9} \mathrm{He}$ attributed downward price rigidity to the Full Employment Act of 1946, which encouraged businessmen to believe in the inevitability of future expansionary policy, "the spread of 'target' pricing,' and the "demands of organized labor", (1971, p. 129).

Warburton anticipated the Keynesian-monetarist debate of the 1960s by a decade and more. His 1951 paper "The Misplaced Emphasis in Contemporary Business-Fluctuations Theory" is his best known and 
most important contribution. ${ }^{10}$ In it he took issue with Keynes and his followers who "have placed great emphasis upon maladjusted savingsinvestment relationships as a basic causal factor in business fluctuations" [1966, ch. 4 (1946c), p. 73]. He argued that

the emphasis of contemporary economists . . . has been misplaced, because a far more potent factor of economic instability in recent years, namely, erratic variation in the quantity of money has been ignored.

Warburton compared the cyclical behavior of the Keynesian psychological factors-liquidity preference, the propensity to consume, and the prospective yield on new capital (MEC)— to that of the quantity of money over the period 1919-45. His proxy for liquidity preference was "the ratio of cash balances held by individuals and business to their expenditures for the final products of the economy" (Cambridge k). ${ }^{11}$ Evidence that deviations of Cambridge $k$ from its trend tend to move opposite to those of the quantity of money and to follow them led Warburton to the conclusion that:

liquidity preference is primarily a function of deviation in the quantity of money from a normal rate of expansion and should therefore be regarded as a dependent, rather than an independent, variable in the set of equations used in the Keynesian type of analysis; and ... changes in liquidity preference should be regarded as an accentuating, rather than an originating, factor in business depression. [1966, ch. 4 (1946c), pp. 79-80]

He also reported that "the amplitude of variation in the propensity to consume appears to have been small relative to the amplitude of variation in the quantity of money" (p. 80), and since its movements were countercyclical, it was not an important cyclical factor. As a proxy for the MEC, he examined the value of corporate security issues for productive use, which tended to lag movements in the quantity of money. He concluded that

the expectations of business regarding the prospective yield on new capital are dominated by the experience of the recent past and should be regarded as an accentuating, rather than an originating, factor in business fluctuations. [1966, ch. 4 (1946c), p. 81]

Warburton also brought to bear historical evidence on the relation between money and business cycles. For the period 1835-85, he found that annual cycles in bank note circulation and deposits, as given in Amasa Walker's Science of Wealth, tended to precede changes in output, as measured by NBER reference cycle dates. ${ }^{12}$ His evidence also suggested that changes in money, largely the result of changes in highpowered money, were independent of changes in income. 
In addition, Warburton found that from the third quarter of the nineteenth century until the establishment of the Federal Reserve System in 1914, monetary disturbances produced by external forces (adherence to the international specie standard) and exacerbated by the banking system accounted for cyclical changes. However, since 1914, he argued that countercyclical monetary policy tended to worsen business fluctuations, citing as prime examples the policy mistakes which produced the great contraction of $1929-33$, and the recession of $1937-38 .^{13}$

\subsection{Quantity Theory of Money}

In the course of his writings, Warburton developed an empirically useful version of the quantity theory of money. He clearly distinguished between the long-run or equilibrium version of the theory and the shortrun or disequilibrium version [1966, Introduction and ch. $8(1949 \mathrm{~b})] .^{14}$ For purposes of empirical measurement of the long-run influence of the quantity of money on the level of prices, as well as the effect of short-run variations in money on aggregate spending, Warburton used an adaptation of Fisher's Equation of Exchange: ${ }^{15}$

$$
M_{t} R_{t}=P_{t} Q_{t},
$$

where

$M_{t}=$ the volume of money relative to the volume in a selected base year, with $M$ usually defined as $M_{2},{ }^{16}$

$R_{t}=$ the rate of use of money relative to the base year,

$P_{t}=$ an index of prices of final output relative to the base year,

$Q_{t}=$ the quantity of output of final products relative to the base year. ${ }^{17}$

The quantity theory and the equation of exchange served as the framework for his analysis of (1) the secular behavior of velocity, money, and prices, (2) the Great Depression, and (3) inflation in World War II.

\subsubsection{Secular Behavior of Velocity, Money and Prices}

Warburton presented data by decades, 1799-1939, and annually, 1909-1947, on the long-run decline in velocity of somewhat more than 1 percent per year, ${ }^{18}$ and on the stability of the long-run trend in the interwar period excluding 1930-35. ${ }^{19}$ His findings indicated that even in periods of extreme monetary instability, velocity was relatively stable.

To test whether the quantity theory enabled one to explain changes in the price level in the interwar period, Warburton developed an index of "demonstrated capacity" on the argument that "productive capacity, used or unused, has more relation to the price level than the actual rate of production" [1966, ch. 6 (1945d), p. 133]. To this index, on the base 1923-28 (a period of full employment) he applied a measure of the secular increase in desired real money balances of 1.4 percent per 
year, which he then compared to the actual average annual quantity of money relative to the base for the period 1919-1943. The ratio of actual money to the need for money was close to the measured index of prices of final products in the majority of nonwar years. An unusual accumulation of inventories in 1920, a tendency for money balances to be stable in 1929, and special wartime developments in 1942-43 seemed to him to account for the exceptional years. Warburton concluded:

Excluding periods of war, variation in the quantity of money, relative to the demonstrated capacity of the nation to provide goods and services and the established monetary habits of the population, is the overwhelmingly dominant factor responsible for changes in the level of prices of goods and services. [1966, ch. 6 (1945d), p. 138]

\subsubsection{The Great Depression}

Warburton's explanation of the Great Depression hinges on the failure of annual monetary growth to equal that required for continued full employment at stable prices. Using annual data, he estimated the required rate of monetary growth per capita as the calculated full employment growth per capita of 1.5 percent per year plus the secular growth in the demand for real money balances per capita of 1.5 percent per year. The required monetary growth rate and actual monetary growth were similar, 1923-1928, but actual growth rates began to fall significantly below the 3 percent trend in 1929, bringing the depression in its wake.

. . . in 1929 the decline in prices normally resulting from monetary deficiency was retarded, for in that year individuals continued their normal volume of purchases by accelerating the rate of use of money and by ending the year with a substantial loss in their cash balances. This situation could not continue long, and prices of final products dropped sharply from 1930 to 1933 with the reduction in the volume of money. Monetary contraction was followed, with a year's lag, by a decline in the rate of use of money, measured by the ratio of expenditures for final products to the cash balances of individuals and business. This was a natural and inevitable effect of monetary contraction, because individuals and enterprises were faced with the necessity, as their cash balances dwindled, of attempting to conserve them by postponing as many expenditures as possible. [1966, ch. 5 (1945b, 1953a), pp. 116-117] $]^{20}$

He calculated the shortfall in the rate of monetary growth in 1933 to be 57 percent of the required rate. He concluded that, had the monetary authorities maintained the 1923-1928 rate of monetary growth, instead of the Great Contraction of 1929-1933, the United States would have experienced "a moderate business depression . . in 1930." 21 


\subsubsection{Wartime Inflation}

Warburton used the quantity theory framework to forecast the level of prices for years following 1943. He forecasted the increase in the quantity of money, 1943-1945, based on an assumed rate of government expenditures and the amount to be financed by bond sales to the commercial banks, which, combined with a stable trend in velocity and a decline in consumer goods production led to upward biased predictions of price rise. ${ }^{22}$ However, with corrected estimates of government expenditures and proper allowance for wartime controls and the tendency of households to defer consumption, his model predicted inflation in the postwar period rather accurately.

In his analysis of the "inflationary gap," 23 which he identified with excess supply of money, ${ }^{24}$ Warburton did not develop the concept of inflation as a tax on money balances, so that holders have to replenish existing balances to maintain their real value constant. Hence he failed to note that it is the reduction in private real expenditures resulting in a transfer of real resources to the government that closes the gap. ${ }^{25}$

\subsection{Savings, Debt, and Liquidity Preference}

In a series of articles written between 1947 and 1950, Warburton expanded his criticism of Keynesian economics and effectively argued that most of the differences between Keynes and the Classics can be formulated as empirical questions. He focused his critique on (1) the notion of liquidity preference, and (2) the theory of deficit spending.

\subsubsection{Liquidity Preference}

Warburton disputed the relationship between money and velocity in Keynesian theory, namely, velocity and the rate of interest vary positively, while money and the rate of interest vary inversely, so that money and velocity "tend to be compensatory." In this connection, he cited the evidence he had assembled on the lag in deviations from trend of velocity with respect to deviations from trend of money and the positive correlations of the two sets of deviations. ${ }^{26}$

Warburton also criticized Tobin's evidence on the interest elasticity of the demand for "idle deposits," derived from the ratio of bank debits to demand deposits as a measure of velocity. ${ }^{27} \mathrm{He}$ argued that bank debits, largely reflecting payments for property and other technical transactions, were an unreliable measure of total payments, and that time deposits should be included in the definition of money. Conducting his own test, Warburton found little relationship between circuit velocity and short- and long-term interest rates [1966, ch. 12 (1948b), p. 271]. He concluded that Tobin had documented a relationship be- 
tween the volume of security speculation and the short-term interest rate.

In addition, he denied that liquidity preference could independently produce variations in economic activity, since the lead in movements in money over those in velocity contradicted the hypothesis. The evidence that changes in velocity generally followed changes in money made it difficult to conceive of the private nonbank sector as an important independent source, through decisions to hoard, of economic instability. ${ }^{28}$

\subsubsection{A Critique of Deficit Spending}

One of Warburton's most important contributions to the monetarist position was his clear statement of the view that fiscal policy not financed by money is ineffective. ${ }^{29} \mathrm{He}$ argued that government expenditure financed by taxation and borrowing from the private sector other than banks affects spending only to the extent it affects velocity, which was possible in the short run [1966, ch. $11(1945 \mathrm{c})$, p. 237].${ }^{30}$ However, government expenditure financed by borrowing from the banking system results in monetary expansion which directly affects spending.

In contrast to well-established Keynesian doctrines, Warburton stated that deficit spending by government or the business sector, financed by nonbanking sources, could not alter the size of the income stream beyond possible effects on the velocity of use of money. ${ }^{31}$ Only spending by government or the business sector financed by borrowing from the banking system, by enlarging the volume of money, which multiplied by velocity, constituted the income stream, provided a net increase in income. As a simple test of these propositions, Warburton compared movements in the level of income and of money adjusted for the long-term trend in velocity and the government deficit from 1919 to 1941 . He concluded: ${ }^{32}$

. . . changes in the size of the income stream are much more closely related to changes in the volume of money, adjusted for the trend in the volume of money held as a store of value, than to the amount of government deficit spending or to such spending plus business spending for capital purposes.

In place of fiscal policy, Warburton proposed monetary policy as "the chief key to a continuously expanding national income" and underscored neglect of the importance of monetary policy as the chief shortcoming of the writings of his Keynesian contemporaries. ${ }^{33}$

\subsection{Monetary Policy}

Throughout his work, Warburton continually stressed one overriding theme: unstable monetary growth was largely responsible for economic 
instability that could have been avoided had the Federal Reserve followed a monetary rule of a steady rate of monetary growth. ${ }^{34}$ Systematically, over a period of thirty years, Warburton constructed a strong case against the use of discretionary monetary policy by examining the record of the Federal Reserve System since $1914 .{ }^{35}$ His criticism encompassed the following points: (1) the record of unstable monetary policy; (2) the variability of lags in monetary policy; (3) the inadequacy of central banking theory; (4) money and interest rates-the confusion of credit policy with monetary policy; and (5) the inadequacy of research.

\subsubsection{The Record of Unstable Monetary Policy}

In Warburton's view, the record of monetary instability has been worse since the Federal Reserve System was established. ${ }^{36}$ According to him, of the five tasks for which the System was primarily designed, ${ }^{37}$ from 1919 to the 1950s, it paid adequate attention only to the first: providing sufficient hand-to-hand currency. Because of excessive concern over the character of bank assets, it failed to guarantee convertibility between deposits and currency during the Great Contraction without disturbing the banks' reserve position-its second task..$^{38}$ In addition, it paid insufficient attention to the control of the quantity of money, because of its emphasis on qualitative rather than quantitative guides to its actions and on loan and credit policy. ${ }^{39}$ The doubling of reserve requirements in 1937 , which led to a massive contraction of bank credit and the money supply and the ensuing business decline, was a policy mistake of the first order ${ }^{40}$ The mistake was a consequence of the System's lack of understanding of the precautionary character of excess reserves as well as the relationship between the New York banks and their correspondents. The System's policy of supporting the prices of government securities during World War II made monetary policy subservient to the needs of the Treasury and fueled the inflation of 1941-1948. ${ }^{41}$ Finally, the policy in the 1950s of "leaning against the wind" aggravated fluctuations in economic activity because of the perverse timing of Federal Reserve actions. ${ }^{42}$

\subsubsection{Variability of the Lag in Monetary Policy}

Warburton provided statistical evidence on the variability of the lag by comparing the dates of cyclical peaks and troughs with the earlier peaks and troughs in member bank reserves. ${ }^{43}$ In a more elaborate analysis, ${ }^{44}$ he compared the lags between major policy actions, effective bank reserves, changes in the quantity of both $M_{1}$ and $M_{2}$, and finally changes in final product expenditures. He found a range of 3 to 11 quarters between monetary policy downturns and the beginning of business downswings, with shorter lags for policy expansions and business upswings. In addition, lags between changes in policy and changes 
in money tended to be short, about one quarter, while those between changes in money and changes in spending tended to be considerably longer.

\subsubsection{Theory of Central Banking}

Warburton effectively criticized the Federal Reserve System for operating on a weak and ambiguous theoretical basis. The convertibility theory of central banking, the underlying theory of the Federal Reserve Act of 1914, which took for granted that the private sector would provide adequate control of the quantity of money so long as the Federal Reserve maintained convertibility of one form of money into another, was abandoned by the late 1930s because of the evident failure of policies based upon it. ${ }^{45}$ Yet the Federal Reserve never fully accepted the "responsibility" theory of central banking, which enjoined the monetary authority to exercise control over the quantity of money to prevent either price inflation or deflation, largely because of its belief that

monetary policy has little influence on economic stability, and that the major cause of the inadequate use of the country's economic resources and price fluctuations is variation in the rate of use of money. [1966, ch. 14 (1946b), p. 314]

Warburton noted that this view reflected an erroneous conception of velocity behavior and the inadequacy of economic research at the Federal Reserve. ${ }^{46}$

\subsubsection{Money and Interest Rates}

An important theme in Warburton's writings is the Federal Reserve System's mistaken use of interest rates as both a guide to and technique of monetary policy. ${ }^{47} \mathrm{He}$ traced the System's emphasis on interest rates to its confusion of money and $\mathrm{credit}^{48}$ and to

the general identification of monetary policy with interest rate control or manipulation . . . implicit throughout Keynes' General Theory ... [as well as] contemporary literature on business fluctuations. [1966, ch. 4 (1946c), p. 97]

With respect to the first, the emphasis on the Federal Reserve Act upon meeting loan needs indicated a confusion of the demand for loans and the demand for money, highlighted by ambiguity in usage of the words "money" and "credit," as the System's references to "the supply, availability, and cost of credit," and "supply, availability, and cost of money." 49 Warburton distinguished between the interest rate as "the rental fee for the use of money" and an incorrect interpretation as "the purchase price of money." 50 An increase in the demand for money by 
the public is acted upon not by requests for loans at banks but by spending a smaller fraction of its cash receipts than it formerly did. ${ }^{51}$ The Federal Reserve, however, views interest charged by banks as a fee paid for the creation of money, not as a rental fee for the use of money, hence operates with the notion that control of the interest rate will have a significant effect on the volume of money in existence. ${ }^{52}$

Warburton stressed that the rate of interest is determined by the demand for and supply of loans, although excessive monetary expansion may temporarily lower the rate just as monetary contraction may temporarily raise the rate..$^{53}$ Business instability traceable to monetary instability induced interest rate fluctuations, so that manipulation of the interest rate would not eliminate the monetary instability responsible for business instability. ${ }^{54} \mathrm{He}$ recommended that ${ }^{55}$

(1) monetary policy should be focussed directly upon the determination of the volume of money which is needed for business stability at a high level . . . and (2) the rate of interest should be left free to fluctuate according to the pressures of the market in which money is offered for rent. [1966, ch. 13 (1945a), p. 289]

\subsubsection{Inadequacy of Research}

An outstanding reason for faulty monetary policy, according to Warburton, was inadequate research and analysis at the Federal Reserve. ${ }^{56}$ He cited the following examples:

(a) lack of recognition of the need for growth in the quantity of money, ${ }^{57}$

(b) use of the ratio of bank debits to average deposits as a measure of velocity, which led to the erroneous conclusion that there was little relationship between money and economic activity, ${ }^{58}$

(c) neglect of research to develop guides to and techniques of monetary policy, a search for policy actions by other government agencies in explanation of economic effects attributable to the System's own operations, and emphasis on banking and credit policy irrelevant to control of the quantity of money, ${ }^{59}$

(d) failure to develop statistical series required for appropriate monetary policy, ${ }^{60}$

(e) faulty analysis underlying the decision to double reserve requirements in $1937,{ }^{61}$

(f) inadequate basic data as the reason monetary policy in wartime and postwar years was subservient to Treasury needs. ${ }^{62}$

These strictures on the System's research record were made in the 1940s and 1950s. Warburton did not temper them in his submission to the Hearings before the House Subcommittee on Domestic Finance in 1964:

The lack of research on the relation of changes in the supply, velocity, and value of money to fluctuations in output, employment, and gross 
national product becomes most evident when inquiries are made regarding the character of the information used by the Federal Open Market Committee in arriving at its decisions. It is not known what quantitative guides, if any, the Committee uses in deciding what rate of growth in money or bank reserves is needed or how much fluctuation is desirable when they adopt differing degrees of "restraint" or "ease." The policy record of the Committee published each year in the annual report of the Board of Governors does not provide such information. This inadequacy in the analytical and statistical background for formulation of monetary policy suggests that any new legislative guidelines for Federal Reserve policy should be framed in such a way as to foster-and in fact require - such research as a continuing activity of the Board of Governors. (P. 1324)

\subsection{Proposals for Monetary Reform}

Warburton did not limit his contribution to criticism of U.S. monetary policy. He was a forceful advocate of a number of proposals for monetary reform. These included suggestions (1) to implement a monetary growth rule; (2) to reorganize the Federal Reserve System; (3) to improve bank supervision; (4) to coordinate monetary and fiscal policy; (5) to include nonmember banks in the Federal Reserve System. In addition, he argued in favor of (6) maintenance of the prohibition of interest payments on demand deposits; and (7) international monetary reform.

\subsubsection{A Monetary Growth Rule}

Warburton proposed that Congress revise the Federal Reserve Act to include provisions for a monetary rule as a replacement for countercyclical monetary policy. ${ }^{63} \mathrm{He}$ would shift the duties of the Federal Open Market Committee to the Board of Governors, and provide for technical studies on the appropriate definition of money, the rate at which money is needed, and the rate of growth of real national output consistent with "maximum employment, maximum use of resources, and maintenance of price stability." 64 As an interim rule, until the technical studies were completed, he would instruct the governors to provide reserves to member banks adequate to maintain a 3 percent per year growth rate of money, for a given definition. ${ }^{65}$

\subsubsection{Reorganization of the Federal Reserve System}

A shift of the powers of the Federal Open Market Committee to the Board of Governors has been referred to. Warburton favored this change because he regarded the diffusion of decision-making power among the various Reserve Banks and conflicts between the Banks and the Board as obstacles to the formulation and execution of policy in the '20s and '30s. ${ }^{66}$ 


\subsubsection{Improvement of Bank Supervision}

Warburton would relieve the Federal Reserve authorities of duties unrelated to monetary policy operations. He would lodge responsibility for bank supervision primarily with the FDIC because the soundness of individual banks has a direct effect on the Corporation's financial resources. ${ }^{67}$

\subsubsection{Coordination of Monetary and Fiscal Policy}

Warburton suggested consolidating in a new department of the executive branch of the Federal government the agencies responsible for monetary policy, bank supervisory policy, and loan policy, ${ }^{68}$ but with strict separation of monetary policy from both fiscal and debt operations, loan policy, and bank supervision. Given such separation of monetary policy, Warburton favored consolidation as facilitating the formulation of basic government policies, reducing the number of agency heads the President confers with, and providing better means for cooperation among the banking and loan agencies. ${ }^{69}$

\subsubsection{Nonmember Banks and the Federal Reserve System}

Warburton would impose reserve requirements on nonmember banks, not because their present exemption hampers monetary policy, but because member banks may choose to give up membership in the System and nonmember banks may expand relative to country member banks. ${ }^{70} \mathrm{His}$ scheme to enlarge participation in the System would include making available to all banks with deposit obligations the right to borrow in case of need at Reserve Banks. ${ }^{71}$

\subsubsection{Prohibition of Interest Payments on Demand Deposits}

Warburton's argument in favor of the prohibition was based on equity: if payment of interest on demand deposits were allowed, small depositors would be discriminated against. Because charges are levied on both senders and recipients of checks, in his view, they fall more heavily in relation to the number of transfers on individuals with smaller accounts than on business firms with larger accounts. ${ }^{72}$ Quantity discounts and the comparative bargaining power of large bank depositors thus discriminate against small account holders. Rather than removal of the prohibition of explicit interest, he would urge discontinuation of "a discriminatory and inequitable method of charging for deposit transfers." 73 Warburton thus regards the provision of bank money to be a public good ${ }^{74}$ and would regulate the banking industry just as railroads are regulated. 


\subsubsection{International Monetary Reform}

In 1953, Warburton proposed a modification of the role of gold in international monetary arrangements. He suggested that the world's stock of gold be an international asset, with the IMF as the world's central banker. ${ }^{75}$ To prevent overissue, the international medium of exchange, consisting of drafts on gold accounts, would have no fiduciary element whatever. His plan involved abolition of the gold reserve requirements for Federal Reserve notes and deposits; payment of the capital subscriptions of various nations to the IMF in gold; authorization of gold loans to members by the IMF and of gold deposits by national central banks for credit to their IMF accounts; issue by the IMF of gold obligations in the form of accounts with national central banks; and the maintenance of stated rates at which central banks would buy and sell gold certificates or drafts on accounts of the Fund. ${ }^{76}$ Warburton believed that the Fund monetary unit, and hence gold, would be a composite of the purchasing power of the currencies of the main industrialized countries, and that if U.S. monetary policy were such that U.S. price stability was maintained, that would tend to produce stability in the purchasing power of the IMF currency. ${ }^{77}$

\subsection{An Evaluation of Warburton's Work}

Warburton's chief contribution was the injection of new life into the quantity theory of money during a period when research on monetary factors was all but moribund. ${ }^{78}$ At least six important aspects of that contribution may be noted.

First, Warburton revived monetary disequilibrium theory. His emphasis on variations in monetary growth as a key cause of business fluctuations and his systematic presentation of empirical evidence that turning points in money preceded those in economic activity paved the way for later research on money and business cycles by Friedman and Schwartz. ${ }^{79}$ His scathing theoretical and empirical attack on the alternative Keynesian view was a forerunner of the comparison of money and autonomous expenditure by Friedman and Meiselman. ${ }^{80}$

Second, Warburton restated the quantity theory of money: In the long run, money and prices tend to be proportional while in the short run, exogenous changes in money, interacting with a stable velocity, produce changes in real output and prices. On the basis of the restatement he proceeded to examine systematic evidence on the stability of velocity and on the relationship between money, prices and output. His empirical work showed velocity to be relatively stable over the cycle and characterized by a long-run secular decline, anticipating later findings by Friedman. ${ }^{81}$ In Warburton's attack on Tobin, he presented 
crude but effective evidence that velocity is not significantly affected by the interest rate and that causality over the business cycle runs from money to economic activity rather than the other way around, themes later stressed by Friedman. ${ }^{82} \mathrm{He}$ also found a close relationship between money, prices and output both in periods of deflation and inflation, again a forerunner of later research by Friedman and Schwartz, Cagan, Brunner and Meltzer, and others.

Third, Warburton challenged Keynesian orthodoxy with respect to the theory of deficit spending. He advanced the views that fiscal policy matters only to the extent that it is financed by money, that the community will discount future taxes required to pay the interest on bond finance, and that government spending will serve as a substitute for private spending. He offered evidence that variations in money are more closely related to variations in income than are variations in the deficit, a predecessor of work by Friedman, Bailey, Andersen and Jordan. Although Warburton never used regression techniques in analyzing the evidence, most of his conclusions have been substantiated by later research using such techniques.

Fourth, Warburton demonstrated the important role of monetary policy in U.S. economic history. His examination of the record of the Federal Reserve System from its founding until the Korean War established the case that poor discretionary policy was largely responsible for the great swings in economic activity. In his analysis of the Great Depression, he argued that monetary contraction was responsible for the depth and duration of the depression, and that, had the Federal Reserve not engineered the massive decline in money over the period 1929-1933, the United States and perhaps the world would have experienced only a mild recession. These views anticipated those of Friedman and Schwartz ${ }^{83}$ as also his evidence that the lags of monetary policy are long and variable.

Fifth, Warburton provided an analysis of the analytical errors underlying Federal Reserve operations. He attacked the inconsistency and inadequacy of the theory underlying central banking in the United States. In particular, he decried the emphasis on loan rather than monetary policy, and on the quality rather than the quantity of bank assetsa legacy of the real bills doctrine. He demonstrated that the interest rate was not useful either as a guide or a technique of monetary policy. In addition, the System's failure to base policy decisions on appropriate statistical data went a long way to explain the mistakes it made.

Sixth, convinced of the shortcomings of discretionary policy, Warburton early and strongly advocated a monetary rule of a steady growth rate of money. The magnitude of the growth rate was to be determined by the growth rate of real output, secular change in the demand for money, and the goal of price stability and full employment. His em- 
phasis on quantitative guidelines for a monetary growth rule was seconded by Friedman and others and has apparently been adopted by policy makers in the United States and other countries.

In conclusion, Warburton's early presentation of the case that "money matters" entitles him to the designation of Pioneer Monetarist. Perhaps the chief explanation of the limited extent of his influence on his contemporaries is that, at the time Warburton began to publish, events that would call into question the prevailing Keynesian orthodoxy had not yet unfolded. Those who were not persuaded years ago by Warburton's percipient analysis have lived to see events vindicate it.

\section{Notes}

1. See Warburton (1935), where he attributed the "great plateau of 192329" to the expanded use in the USA of the automobile and the concomitant increase in demand for real estate. The inevitable downturn in 1929, he argued, reflected an overextension of the real estate and stock markets, the decline in bank credit acting as the accentuating force. It is interesting to note the similarity of Warburton's early views and Alvin Hansen's (1939) stagnationist thesis. Later, Warburton vigorously attacked that thesis (1948a), and [1966, ch. 3 (1950d)].

2. Warburton [1966, Introduction, 3-7].

3. Warburton [1966, ch. 1 (1950b)].

4. According to the traditional theory of monetary disequilibrium, changes in the quantity of money ultimately produce a new equilibrium price level, but that adjustment takes time, and involves changes in relative prices, profits, and output [1966, ch. 4 (1946c), p. 86]. Moreover, improvements in profit margins in the upswing (deteriorations in the downswing) tend to increase the rate of use of money (decrease in the downswing), so that movements in velocity amplify those in money (ibid., 88). Finally, according to the Classical Equilibrium theory, the rate of interest (i.e., the natural rate) is determined by the forces of thrift and productivity (i.e., the demand and supply of loanable funds), but changes in the quantity of money by temporarily changing the supply of loanable funds induce interest rate adjustments to reflect changing profit opportunities (ibid., 90-92).

5. Twenty-five years later, Warburton $(1975,435)$, again complained that:

John Maynard Keynes, and most of his contemporary economists, in seeking to understand how the resulting great depression had occurred and to devise a remedy, remembered the equilibrium theory of their nineteenth and early twentieth century predecessors, but failed to remember the concomitant theory of monetary disequilibrium; and in consequence did not even try to look carefully at the factual record with respect to the stock of money.

6. See Warburton [1966, ch. 2 (1948c), ch. 3 (1950d), and ch. 8 (1949b)].

7. Warburton (1967).

8. Elsewhere Warburton [1966, ch. 2 (1948c), 37] discussed the role of "fixed and sticky costs," narrowing profit margins, which induced firms to reduce output, as well as the effects of 'unanticipated inventory accumulation'. 


\section{Warburton (1971).}

10. In this regard, see also Warburton's critique [1966, ch. 3 (1950d)] of Alvin Hansen (1949), in which he argued against Hansen's view that changes in the propensity to spend exert an independent effect on the level of economic activity through an effect on the quantity of money rather than the rate of use of money. Warburton noted that Hansen's view "rests on the assumption that the quantity of money is determined by the decisions of spenders; and that assumption appears to be based on a lack of understanding of the nature and behavior of banks" (ibid., 59).

11. Warburton [1966, ch. 4 (1946c), 75].

12. Warburton (1958).

13. Warburton (1962).

14. In the long run, the level of prices is determined by the quantity of money, given a stable secular trend in "circuit velocity of money," and the growth of real output, itself determined by the growth of output per capita and the growth of population [1966, ch. $8(1949 b), 186]$. In the short run, it is deviations from trend in the quantity of money which induce deviations from trend in velocity, the two forces in turn producing deviations from trend in aggregate spending, which is thus broken into changes in output and prices [1966, ch. 4 (1946c)].

Throughout Warburton's work, the quantity of money is assumed to be exogenous-the quantity of money is dependent on "the policies and operations of money-issuing agencies. Under modern conditions these are dominated by central bank policies"' [1966, ch. 8 (1949b), 186].

"Circuit velocity of money" is also assumed to be stable, depending "basically upon the customs and habits of users of money," which "determine the order of magnitude and the trend in monetary velocity" (ibid.).

15. Warburton [1966, ch. 5 (1945b), 105-107 and ch. 8 (1949b), 186].

16. Warburton explained his preference for $M_{2}$ over $M_{1}$ in calculating velocity as follows:

Calculations of monetary velocity made on the basis of demand deposits plus currency have been greatly affected by factors which influenced the classification of deposits without altering their use. For this reason such measures of monetary velocity are less significant for general economic analysis than measures of monetary velocity based on the total quantity of money including time deposits. [1966, ch. 9 (1949a), 206]

A further argument he offered in favor of inclusion of time deposits was that they serve as "a store of value held primarily for use at a future time as a means of payment" [1966, ch. 7 (1946a), 148].

17. Warburton's preferred measure of $Q$ differs from GNP “by excluding changes in business inventories, net exports of goods and services, and net changes in monetary stock" [1966, ch. 5 (1945b), 105]. His adaptation of the equation of exchange also included trend-adjusted index numbers, using the concept described in recent years as potential real GNP or potential real output growth, which he referred to as "full production" or "normal production." Selecting the years 1923-28 as the closest approach to "normal production" after the establishment of the Federal Reserve System, he computed trends as a statistical framework for analysis of business fluctuations. The trend values were taken to represent equilibrium conditions. Deviations from the trends expressed as percentage ratios represented disequilibrium conditions, useful for observing coincident and lead-lag relationships.

18. Warburton [1966, ch. 9 (1949a)]. 
19. Warburton [1966, ch. 6 (1945d), 131].

20. Reduced expenditure led to a decline in production because of (1) "sticky costs"; (2) the decline in velocity which directly reduced the volume of sales; (3) "falling prices and reduced sales [which] reverberated upon individual incomes, inducing further reductions in sales of final products"; and (4) "the unused productive capacity accompanying the reduced demand for consumers" goods and services [which] induced a much more drastic and violent reduction in the demand for capital equipment [1966, ch. 5 (1945b) (1953a) 117].

21. Warburton [1966, ch. 5 (1945b) (1953a) 119 and ch. 8 (1949b), 180]. His results from quarterly data, a few years later, were similar. Money held by individuals declined from a peak, relative to the needed growth trends, of 100.2 in the second quarter of $\mathbf{1 9 2 8}$ to a low of $\mathbf{5 8 . 2}$ in the fourth quarter of 1933.

22. Warburton (1949c).

23. Warburton $(1943,1944,1945 e)$.

24. ". . . (the) net change in bank loans and investments and monetary metal stocks, which, ... , is the amount of government borrowing from banks in excess of reduction of indebtedness of other borrowers to the banks, (or alternatively as the) increase in bank deposits and currency in the hands of individuals and business" $(1943,368)$. This should be viewed in the context that most of Warburton's contemporaries believed that any excess of government expenditures over receipts, however financed, created the gap. See Warburton (1945e).

25. See Friedman (1953). In a private communication to us, Warburton notes that he believes the orientation of the inflation gap symposium related to a different issue than the one Friedman analyzed. For Warburton the issue was the future impact of cash balances business and individuals acquired when government spent funds borrowed from banks. The additions to cash balances were received before they were needed to maintain the initial real value of the holdings.

26. Warburton [1966, ch. 12 (1948b)].

27. Tobin (1947).

28. Warburton [1966, ch. 10 (1947)].

29. Warburton [1966, ch. 11 (1945c), 236]:

Fiscal policy as an instrument for increasing economic activity is a combination of (1) monetary policy, for any action increasing the volume of money or changing its rate of flow is a type of monetary policy, and (2) production policy, as expressed in the objects of governmental expenditures. Of these two aspects of fiscal policy, the monetary aspect is by far the more important with respect to the total volume of production or rate of economic activity. In fact, if fiscal policy has no effect on the volume of money or its rate of use in the purchase of products of the economy, the production policy expressed in the objects of government expenditures is a substitution of goods and services ordered by government for goods and services which would be ordered by individuals [emphasis added]. Except for a possible effect upon efficiency, the net effect of fiscal policy upon the total volume of economic activity or production is due solely to its monetary aspect.

30. First-round effects of tax- and bond-financed expenditures on velocity depend on factors such as: "(1) how quickly the government spends the funds after receiving them relative to the use which individuals or enterprises would have made of those funds, (2) in the case of taxation, how the taxes are collected, ... . (3) to what extent purchasers of government bonds restore the 
cash balances used in making such payments or thereafter maintain smaller average cash balances.' [1966, ch. 11 (1945c), 238]

31. In the case of government expenditure financed by borrowing, Warburton argued that the private sector would realize that such financing would entail future taxes and hence the

fiscal (revenue and expenditure) decisions of the government would be neutralized, and we would be reduced to the conclusion that the aggregate savings of individuals are dominated by business decisions respecting the funds they need for capital expansion and replacement. [1966, ch. 10 (1947), 221]

32. Warburton [1966, ch. $11(1945 \mathrm{c}), 252]$.

33. Ibid., 252.

34. For a clear summary of his position, see Warburton $(1971,131)$ and $(1962$, 91-92), where he states:

[T] wo centuries of American experience, with a variety of monetary standards and various criteria for the guidance of central bank operations, support the conclusion that monetary disturbances have been a basic factor in bringing about our depressions and our inflations. That experience suggests that a noncyclical monetary policy is likely to give better results than the recent countercyclical policy, and that we should experiment with central bank policies that produce a steady growth, at a reasonable rate, in the stock of money.

35. Warburton [1966, ch. 17 (1952), 368-69]:

Since the time of establishment of the Federal Reserve System, annual deviations in the quantity of money from a reasonable rate of growth have ranged from more than 30 percent excess to nearly 20 percent deficiency. There is no known need for annual variations in the quantity of money, from the estimated reasonable rate of growth, of more than 2 percent; and annual variations in the quantity of money outside this range have been invariably associated with business instability and with inflation or depression. The range of additional variation for seasonal purposes is probably not more than three percent [1966, ch. 17 (1952b), 368-69].

36. See Warburton [1966, chs. 14-19, especially ch. 14 (1946b)].

37. Warburton $(1962,83)$ :

(1) to provide a method of issuing paper currency by the banking system free from the limitations on national bank notes and readily adjusted in quantity to the varying need for currency; (2) to provide for interconvertibility between such currency and bank deposits without disturbing the reserve position of the banks; (3) to pool a portion of bank reserves and to make them available for the relief of financial stringency in any area or locality; (4) to remove or at least reduce inappropriate seasonal variations in bank credit; and (5) to stabilize the total amount of bank credit and thus promote stability of the total circulating medium. (Warburton, 1962, 83)

38. Warburton [1966, ch. 14 (1946b), 302].

39. Ibid., 301-308.

40. Warburton [1966, ch. 15 (1952a), 324-26].

41. Warburton $[(1962,89)$ and $(1964 a, 1322)]$.

42. Ibid., $(1962,90)$.

43. Warburton [1966, ch. 3 (1950d), 42].

44. Warburton (1971).

45. Warburton [1966, ch. 14 (1946b), 291, 292, 316]. Like Lloyd Mints (1945), Warburton believed this view was based on the real bills doctrine (ibid., ch. 14, 293).

46. Warburton [1966, ch. 14 (1946b), 316]: 
The monetary theory . . . held by the Board of Governors of the Federal Reserve System is based on inadequate examination of factual data and is a barrier to development and adoption of the kind of monetary policy needed for full production without inflation. [1966, ch. 14 (1946b), 316]

47. Warburton [1966, ch. 10 (1947), 233].

48. Associated with the "convertibility theory" and the ambiguity of the criteria for policy in the Federal Reserve Act (see section 9.3, above).

49. See Warburton [1966, ch. 13 (1945a) and ch. 19 (1950c and 1951), 397].

50. Warburton [1966, ch. 13 (1945a), 282].

51. Ibid., 283.

52. Here [1966, ch. 13 (1945a), 285-286], Warburton is referring to the views of the Board of Governors of the Federal Reserve System expressed in the April 1939 Federal Reserve Bulletin, 256, and its 1943 Annual Report, 10.

53. Warburton [1966, ch. 13 (1945a), 286-287].

54. Ibid., 288. He argued that changes in the interest rate cannot be depended upon as a guide to monetary policy because

they must somehow be used in a manner to produce a monetary growth in accord with the need for money generated by growth of population, growth in production per capita, and increased holdings of cash reserves by individuals and business. Interest rates cannot be so used because the rate of interest must be free to respond to real changes in the demand and supply of loan funds, in order to avoid producing monetary maladjustment, and there is no method of judging accurately the "correct" level of interest rates except when monetary maladjustment is avoided. (290)

55. Also see Warburton (1964a, 1321), where he urged the Federal Reserve System to follow a neutral interest rate policy.

56. Warburton [1966, ch. 16 (1952c), 349].

57. Ibid., 344. In the 1920s, Carl Snyder of the Federal Reserve Bank of New York had measured the rate of monetary growth required for price stability, but his efforts were ignored by the Federal Reserve Board.

58. Warburton [1966, ch. 19 (1950c and 1951), 399-400]. As noted in section 5.3. above, he argued that had the Federal Reserve used the ratio of final payments to money held by individuals and firms, they would have found a different result.

59. Ibid., 400-401.

60. Warburton [1966, ch. 16(1952c), 345]. In the 1920s, the New York Federal Reserve Bank had made significant progress in the development of indexes of industrial output, the overall price index, and employment. However, according to Warburton (ibid., 347), the Federal Reserve Board's obsession with stock market speculation in the late 1920 s led to the abandonment of whatever attention had been given to these data.

61. Ibid., 347:

As a basis for its decision . . . the Board estimated that all but a very few member banks could meet this increase through use of their existing excess reserves plus a reduction of one half in correspondent balances with other banks. . . . The Board failed to take into account the impact of such a use of correspondent bank balances on the banks in the money centers, particularly in New York. . . . [They] failed to realize that the New York banks would find it necessary not only to meet the increase in their own reserve requirements but also a portion of the reserve requirements of other banks which had correspondent balances with them.

62. Ibid., 348.

63. Warburton $(1965,289)$.

64. Warburton (1964a, 1325, 1327-1328). 
65. Ibid., 1328. In his earlier studies in the 1940s and 1950s, he advocated a 5 percent per year growth rate in the money stock. This reflected an adjustment for the steady secular decline in velocity of 1.5 percent. The switch to a lower growth rate incorporated the assumption that the turnaround in the trend of velocity since 1950 would continue.

66. Ibid., 1323. As noted in section 9.5. above, Warburton believed that inadequate research at both the Federal Reserve banks and the Board of Governors contributed to the inadequacy of policy in the past. Recent strides in research at the Federal Reserve Bank of St. Louis under the direction of Homer Jones [see Brunner (1977)], as well as research developments at other Federal Reserve Banks and the Board of Governors, may be a response to Warburton's criticism.

67. Warburton [1966, ch. 19 (1950c and 1951), 406]. Also (1963, 355-356).

68. Ibid., 411-412; also (1964a, 1319).

69. Warburton [1966, ch. 19 (1950c and 1951), 411-412].

70. Warburton $(1963,339)$.

71. Ibid., 352.

72. Warburton (1964b, 2085).

73. Despite the payment of implicit interest on demand deposits, Warburton argued the discrimination continues (ibid., 2085).

74. I.e., the deposit transfer system.

75. Warburton [1966, ch. 18 (1953a)]. According to Warburton, use of a national currency, such as sterling in the late nineteenth century, as an international reserve currency, would be acceptable provided the reserve country does not overissue. However, at the time he wrote, he argued that "there is no country which handles so large a portion of world trade and no national currency which is so universally used in international commercial contracts" (389).

76. Ibid., 390.

77. Ibid., 391.

78. See Friedman (1956), Patinkin (1969).

79. Friedman and Schwartz (1963a).

80. Friedman and Meiselman (1963).

81. Friedman (1959).

82. Friedman (1961).

83. Friedman and Schwartz (1963a). 